\title{
鋼管杭による土壤採熱実験と採熱量の予測 \\ EXPERIMENTAL STUDY ON HEAT COLLECTION FROM THE SOIL USING A STEEL PIPE PILE AND ESTIMATE OF THE HEAT COLLECTION RATE
}

\author{
森野仁 夫*, 岡 建雄**, 庄子博幸*** \\ Kimio MORINO, Tatsuo OKA and Hiroyuki SYOUJI
}

\begin{abstract}
For the purpose of using soil as a heat source, we conducted a long-term heat collection experiment employing a steel pipe pile as a heat exchanger with soil. From the experimental data, we confirmed that the quantity of heat collected from the soil per day was to be about $23 \mathrm{kWh}$ and the high performance of coefficient (COP=3.3) for the GSHP, in a stationary state. Numerical calculation results agreed well with the long-term experimental results, which showed that the calculation method could estimate the heat collected rate from the soil during a long-term operation of the heat collection system.
\end{abstract}

Keywords: steel pipe pile, ground coupled heat pump, ground heat collection, simulation 鋼管杭、土壞熱源ヒートポンプ、土壤採熱、シミュレーション

1.はじめに

土䱋をヒートポンプの熱源として利用する技術の研究 開発は、自然エネルギー利用技術や代替エネルギー開発 の一手段として位置つけられ、古くから国内外で行われ てきた。近年においては1970年代後半から北欧や北米で

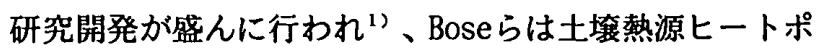
ンプの技術概念を分類し設計方法をまとめている ${ }^{2)}$ 。こ のような経稦を背景に、北欧や北米では空調や給湯を対 象としたヒートポンプ熱源としての土䆣の利用が積極的 に進められているすい、4)。

わが国においては、落藤らが水平管方式、垂直管方式 および直膨方式の土壤熱源ヒートポンプについて、空調

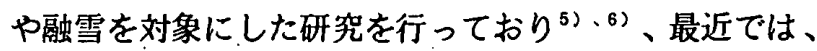
土㙵の凍結・融解を考虑した実験と理論解析を進めてい る”。西岡らは寒冷地における垂直管方式による土境採 熱ヒートポンプの適用可能性を、北海道各地における実 証実験と解析によって明らかにしている8 直管方式について降雨や土㙵の水分移動を考慮した㬰験
と解析を行い、土壌のヒートポンプ熱源としての有効性 を示しているき。また、大橋らは建物の地下外壁を利用 した方式を提案し ${ }^{10)}$ 、竹内・宮本らは比較的温暖な皘雪 地域を対象として、ヒートポンプを用いずに垂直管で採 熱を行う融雪システムの研究開発を行っている ${ }^{11)}$ 。

しかし、現状においてわが国では土壤熱利用システム が実用化されている例は少なく、北海道や北陸地方など の寒冷地や塩害の被害が大きい地域における空気熱源七 一トポンプの代替としての利用や ${ }^{8)}$ 、12)、地下水を汲み 上げない点が評価されての融雪用熱源としての利用 ${ }^{13)}$ ど、数件の実施例が見られる程度である。

この原因の一つとしては土中へ埋設する熱交換器の設 置費用が高く、他のエネルギー供給システムと比較して トータルコストの面で経済的に優位な水準には達してい ない点がある。この点で、建築基礎に用いられる鋼管杭 を土境との熱交換器として使用することができれい゙建設 コストが軽減され、土壤熱利用システムが実用的な競争 力を持ったシステムとして成立する可能性が出てくる。
* 清水建設(侏技術研究所 主任研究員. 博士 (工学)

** 宇都宮大学工学部建設学科 教授・工博

*** 宇都宮大学工学部建設学科 大学院生 - 工修
Institute of Technology, Shimizu Corp., Dr. Eng.

Prof., Dept. of Architecture, Faculty of Engineering, Utsunomiya University, Dr. Eng

Graduate Student, Dept. of Architecture, Faculty of Engineering, Utsunomiya University, M. Eng. 
本研究は、このような観点から鋼管杭を土壌熱利用シ ステムの熱交換器とする可能性に着目し、銅管杭の土壤 との熱交換特性を実験的に明らかにすると共に、システ 么の熱的性能を定量的に評価するための理論解析手法を 開発することによって、その設計方法を確立することを 目的としたものである。

筆者らは、これまで銅管杭を土噇との熱交換器とした 放熱および採熱方法について実験的な研究を行い、鋼管 杭と土壤との熱交換特性を明らかにすると共に、短期の 実験結果を基にした放熱量や採熱量の予測方法について 報告し14)、また、銅管杭による土㙴採熱システムの比較 的長期にわたる熱交換特性について報告して来た ${ }^{15) 、 16) 。 ~}$

土壌を採熱源として利用する場合、鋼管杭のような土 中に埋設した採熱管で採熱できる熱量は、初期には大き な值を示すが土袞の熱応答性が低いため時間の経過とと もに隇少し、土壤からの熱回収量と平衡した時点で安定 する。したがって、長期にわたって使用する土境採熱シ ステムの設計に際しては、土壌との熱交換が安定した状 態における採熱量を知ることが必要となる。

この点で既報 ${ }^{14)}$ で示した結果は短期の実験を基にして おり、実験的には、土袞熱利用システムの長期にわたる 運転特性を明らかにすること、また、解析的には、計算 モデルのいくつかの仮定が、長期の計算においても成 立することを実験結果との検証で確認し、土境熱利用シ ステムの長期性能評価に対する、本計算方法の適用性を 実証することが課題として残されていた。

本報では、1993年11月から半年余りにわたって行った 長期採熱実験の結果を基に、土垍採熱システムの長期運 転特性を明らかにした結果を示すと共に、計算モデルの 長期性能予測への適用性を検討した結果について述へる。

\section{2. 実験方法}

\section{1 実験装置と計測方法}

実験装置の概要を図 1 に示す。銅管杭は外径 $600 \mathrm{~mm} \phi$ 、 肉厚 $14 \mathrm{~mm}$ 、長さ $22.5 \mathrm{~m}$ の打込み杭で土中に垂直に打設され ている。鋼管杭は底部を閉塞して内部に水を封入し、冷 凍機への水の循環用に 2 本の塩化ビニル管(呼び径 $40 \mathrm{~mm} \phi$ ) を、一方はその開口が杭上端から $100 \mathrm{~mm}$ 、他方は杭底部か ら300m位置するように設置している。銅管杭内部の容 量は約 $5.9 \mathbb{m}^{3}$ である。実験装置の機器仕様を図 1 中に示す。 冷凍機は低温用ブライン冷凍機で出力は $10.5 \mathrm{~kW}$ (3USRT)、 圧縮機入力は3.75kWである。

実験では銅管杭内部の水を上部から取り出し、下部へ 注水するように循環させて冷凍機の熱源水とする採熱運 転を行った。採熱運転は9時〜17時までを運転時間とし、 循環水配管の凍結防止のため鋼管杭内部の平均水温が 3 ${ }^{\circ} \mathrm{C}$ となった時点で停止するようにして1日サイクルで繰

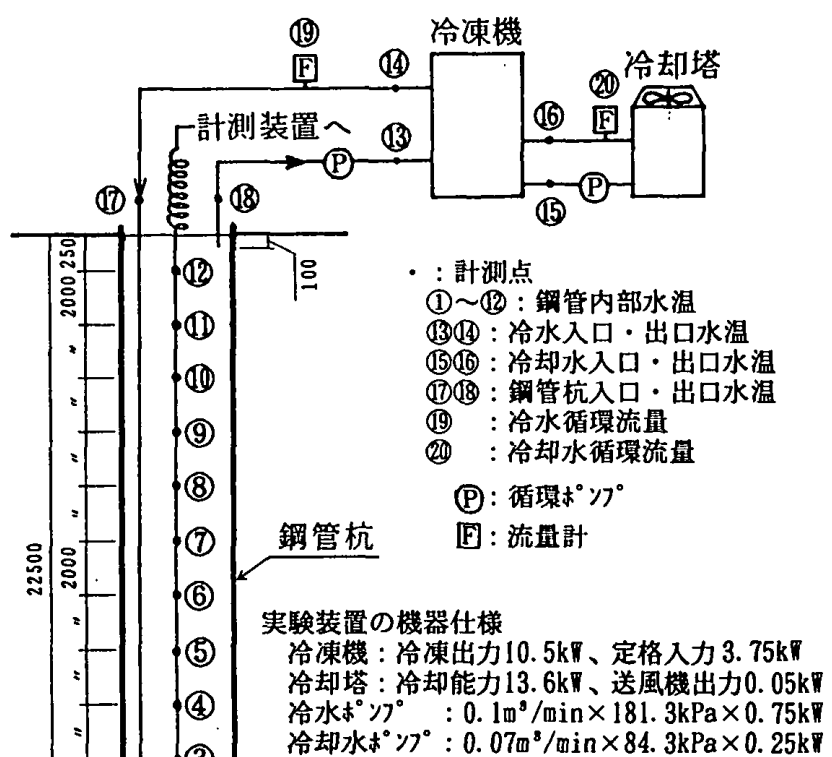

図 1 実験装置

り返し、休日は採熱を行わず自然状態に放置した。実験 期間の循環水量は、実験開始から第 2 週まで $3: 6 \mathrm{~m}^{3} / \mathrm{h}$ 、 第 3 週と第 4 週は $5.0 \mathrm{~m}^{3} / \mathrm{h}$ ししたが、以降は $3.0 \mathrm{~m}^{3} / \mathrm{h} て ゙$ 一定とした。銅管杭内部の水の換水回数は循環水量 3.0 $\mathrm{m}^{3} / \mathrm{h}$ たおいて約 0.5 回/hである。実験は1993年11月25日か ら1994年6月30日までの約 7 力月間にわたって行った。

主な計測点を図 1 中に示す。銅管杭内部水温の垂直分 布（計測点(1) (12)）、冷凍機出入口水温（113）、(14)）、鎆 管杭（11D、(18)）および冷却塔の出入口水温（15)、(16) は T熱電対で計測した。冷凍機（19）と冷却塔（⑩）の循 環流量は電磁流量計で計測し、冷凍機と冷却塔ならびに 冷水循環ポンプと冷却水循環ポンプの消費電力量は積算 電力量計で計測した。計測は自動計測で行い、データは 5 分間隔で記録した。銅管杭周囲の土塎温度は計測して いない。また、参照データとして実験場所から約 $50 \mathrm{~m}$ 離 れた地点の観測孔で実験期間にわたる土壤温度の垂直分

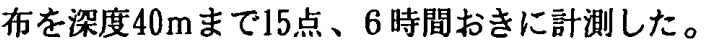

2 . 2 地盤性状

実験場所の土質は図 2 の地盤柱状図に示すとおり、シ ルトと細砂で代表される。ボーリング時の孔内水位は GL-1.8mであり、実験場所の土袞は飽和状態にあると 判定される。土質試験によって得られた土壤の物性值を 表 1 に示す。ここにおいて、土袞の密度、土粒子の密度、 透水係数、含水比、間隙比は、実測值の加重平均値であ る。土㲔の熱伝導率は、含水比、間隙比亡土壌の乾燥密 度から、Kersten と Johansen の実験式 ${ }^{17}$ を参考にして 求めた。土壤の比熱は含水比亡土壤成分の構成比から決 定した。熱拡散率は $\mathrm{a}=\lambda /(\mathrm{Cp} \cdot \gamma)$ の関係から求めた。 
3. 計算方法

\section{1 基礎方程式}

土滾中の熱拡散は、3 次元非定常熱伝導方程式に地下 水の流れを考慮して(1)式で表現される ${ }^{18)}$ 。

$$
\begin{aligned}
& \frac{\partial T}{\partial \tau}+u_{r} \frac{\partial T}{\partial r}+u_{\theta} \frac{1}{r} \frac{\partial T}{\partial \theta}=a\left(\frac{1}{r} \frac{\partial}{\partial r}\left(r \frac{\partial T}{\partial r}\right)\right. \\
& \left.+\frac{1}{r^{2}} \frac{\partial^{2} T}{\partial \theta^{2}}+\frac{\partial^{2} T}{\partial z^{2}}\right)
\end{aligned}
$$

土㲔と鋼管杭内部の水との伝熱量 $q$ 。は、仮想流体温度 $T_{f}^{\prime 19)}$ を用いて(2)式より求められる。

$$
q_{s}=2 \pi \lambda\left(T_{f}^{\prime}-T_{s}\right) / \ln \left(r_{p} /\left(r_{p}-\Delta r\right)\right)
$$

銅管杭内部の水温 $t$ 、は平均温度として扱い、(3)式に より $\mathrm{n}$ 時点の第 1 次仮定水温 $t^{\prime}$ ，算出し、鋼管杭内部 水温が $t^{\prime}{ }_{n}$ に $\Delta \tau$ 時間保持されるとして、(1)式より土 培温度分布を計算した後、(2)式より $q$ eを求めて(4)式に より算出する。この過程では収束計算を行っている。

$$
\begin{aligned}
& t_{w n}^{\prime}=t_{w n-1} \times\left(1-f_{w} / V_{p}\right)+t_{i} \times f_{w} / V_{p} \\
& t_{w n}=t_{w n}^{\prime}-q_{e} / V_{p} / \gamma_{w} / C_{p w}
\end{aligned}
$$

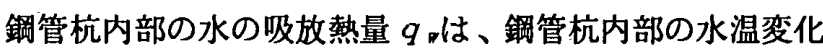
より(5)式で求め、

$$
q_{w}=V_{p} \times\left(t_{w n}-t_{w n-1}\right) \times \gamma_{w} \times C_{p w}
$$

鋼管杭からの採熱量 $q_{r}$ は(6)式から求める。

$$
q_{r}=q_{e}+q_{w}
$$

一方、採熱運転が停止している場合は、鋼管杭内部水 温が $\Delta \tau$ 時間前の水温 $t_{\text {\#n-1 }}$ に $\Delta \tau$ 時間保持されるとし て、(1)式より土铱温度の分布を求め、(2)式より $q_{e}$ を計 算し、 $t_{\# n}$ を(4)式より算出する。

土壤温度の数值解析は、陽解法による差分方程式によ って行った。計算方法の詳細は、既報 ${ }^{14)}$ を参照されたい。 ここで $\quad T:$ 土䇎温度 $\left[{ }^{\circ} \mathrm{C}\right] \quad a:$ 熱拡散率 $\left[\mathrm{m}^{2} / \mathrm{h}\right]$

$u_{r}, u_{a}: r$ 方向、 $\theta$ 方向の地下水流速 $[\mathrm{m} / \mathrm{h}]$

$i:$ 土垶の熱伝導率 $[\mathrm{W} / \mathrm{mk}] \quad r_{p}$ : 鋼管杭半径 $[\mathrm{m}]$

$T_{s}:$ 鋼管杭表面の土䇎温度 $\left[{ }^{\circ} \mathrm{C}\right]$

$f_{\text {I }}$ : 循環水流量 $\left[\mathrm{m}^{3} / \mathrm{h}\right] \quad V_{P}$ : 鋼管杭内部の容積 $\left[\mathrm{m}^{3}\right]$

$t_{i}:$ 循環水入口温度 $\left[{ }^{\circ} \mathrm{C}\right] \quad \tau:$ : 時間間隔 $[\mathrm{h}]$

$\gamma_{\text {: }}$ : 水の密度 $\left[\mathrm{kg} / \mathrm{m}^{3}\right] \quad C_{p}:$ 水の比熱 $[\mathrm{kJ} / \mathrm{kgK}]$

$\mathrm{r}, \theta, \mathrm{z}:$ 円筒座標系の半径・接線・深さ方向

\section{2 計算条件の設定}

土袞温度の計算領域は円筒座標系の半径方向に鋼管杭 表面から $5 \mathrm{~m}$ 、深さ方向に地表面から $25.5 \mathrm{~m}$ の範囲とした。 計算条件として、初期土垣温度は、実験場所から十分に 離れた土壤温度の記録より計算領域全体にわたって17.0 ${ }^{\circ} \mathrm{C}$ とた。境界条件としての地表面温度は土㙵温度と同

\begin{tabular}{|c|c|}
\hline 属生 & 物性値 \\
\hline 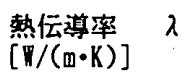 & 0.93 \\
\hline 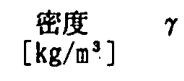 & 1700 \\
\hline$\underset{[\mathrm{kJ} /(\mathrm{kg} \cdot \mathrm{K})]^{\mathrm{j}}}{\mathrm{Cp}}$ & 1.88 \\
\hline $\begin{array}{l}\text { 熱应散率 } \\
{\left[\mathbf{m}^{2} / \mathrm{h}\right]}\end{array}$ & $1.1 \times 10^{-3}$ \\
\hline $\begin{array}{c}\text { 透水係数 } \\
{[\mathrm{m} / \mathrm{h}]}\end{array}$ & $3.6 \times 10^{-6}$ \\
\hline $\begin{array}{c}\text { 含水比 } \\
{[\%]}\end{array}$ & 45 \\
\hline $\begin{array}{cc}\text { 間阥比 } \\
{[-]}\end{array}$ & 1.4 \\
\hline $\begin{array}{c}\text { 土柆子の密度 } \\
{\left[\mathrm{kg} / \mathbb{m}^{3}\right]}\end{array}$ & 2650 \\
\hline
\end{tabular}
一の17. $0^{\circ} \mathrm{C} て ゙$ 計算期間中一定とした。採熱運転時の鋼管 杭内壁の熱伝達率は、竹内らの文献 ${ }^{11}$ を参考に(7)式か ら求め $\alpha=58 \mathrm{~W} /\left(\mathrm{m}^{2} \cdot \mathrm{K}\right)$ とした。

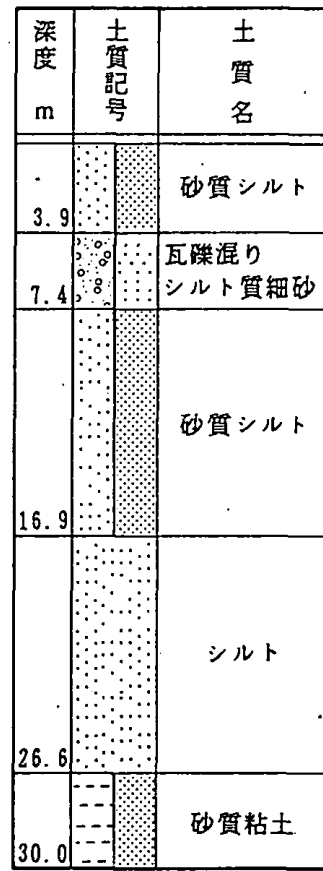

図 2 土質柱状図
表 1 土壤の物性值 $\left(\frac{\alpha D}{\lambda_{w}}\right)^{3}=(3.657)^{3}+\left\{\frac{0.75(R a D / L)^{1 / 4}}{\left(1+\left(0.492 / P_{r}\right)^{9 / 16}\right\}^{+/ 9}}\right\}^{3}$

$$
\begin{array}{r}
\text { ここで D : 鎆管杭の直径 }[\mathrm{m}] \mathrm{L} \text { : 鋼管杭の長さ }[\mathrm{m}] \\
\lambda \mathrm{w}: \text { 水の熱伝導率 }[\mathrm{W} / \mathrm{mK}] \\
\mathrm{Ra}: \text { レイノル数 }[-] \operatorname{Pr}: \text { プラントル数 }[-]
\end{array}
$$

計算領域の土袞は表 1 の物性で均一と想定した。計算 において計算時間間隔 $\Delta \tau$ は $0.01 \mathrm{~h}$ 、円筒座標系における 半径方向の分割幅 $\Delta \mathrm{r}$ は $0.025 \mathrm{~m} 、 \theta$ 方向の分割幅 $\Delta \theta$ は $30^{\circ}$ 、深さ方向の分割幅 $\Delta \mathrm{z}$ は1. $5 \mathrm{~m}$ とし、水位ポテンシ ヤルは $0.01 \mathrm{~m} / \mathrm{m}$ とた。計算において採熱運転中は鋼管杭 入口温度と冷水循環流量を計算入力值として与えた。

\section{4.実験結果および計算値亡の比較}

実験結果の整理では以下に示す記号で各熱量を表した。

Q Q P : 銅管杭からの採熱量

QQG : 土㙵からの熱伝導量

$\mathrm{Q} Q W$ : 鋼管杭内部水の吸放熱量

Q Q R : 冷凍機採熱量

Q Q C : 冷凍機供給熱量

Q L O S : 陸上部における冷水循環系統の熱損失

ここにおいて、QQ P て冷凍機へ供給した熱量であり、冷水循環流量と循環水 の鋼管杭出入口における温度差から求めた。QQWは冷 凍機の運転・停止に伴なう鋼管杭内部水の吸放熱量で、 鋼管杭内部の水の熱容量と、計測点(1)から(12)を容積加重 平均した鋼管杭内部平均水温の単位時間当たりの変化か ら求めた。QQ Gは鋼管杭内部水への周囲土境からの熱 伝導量であり、直接計測することができなかったため、 Q Q G = Q Q P - Q Q W として求めた。Q Q Rは冷凍機 

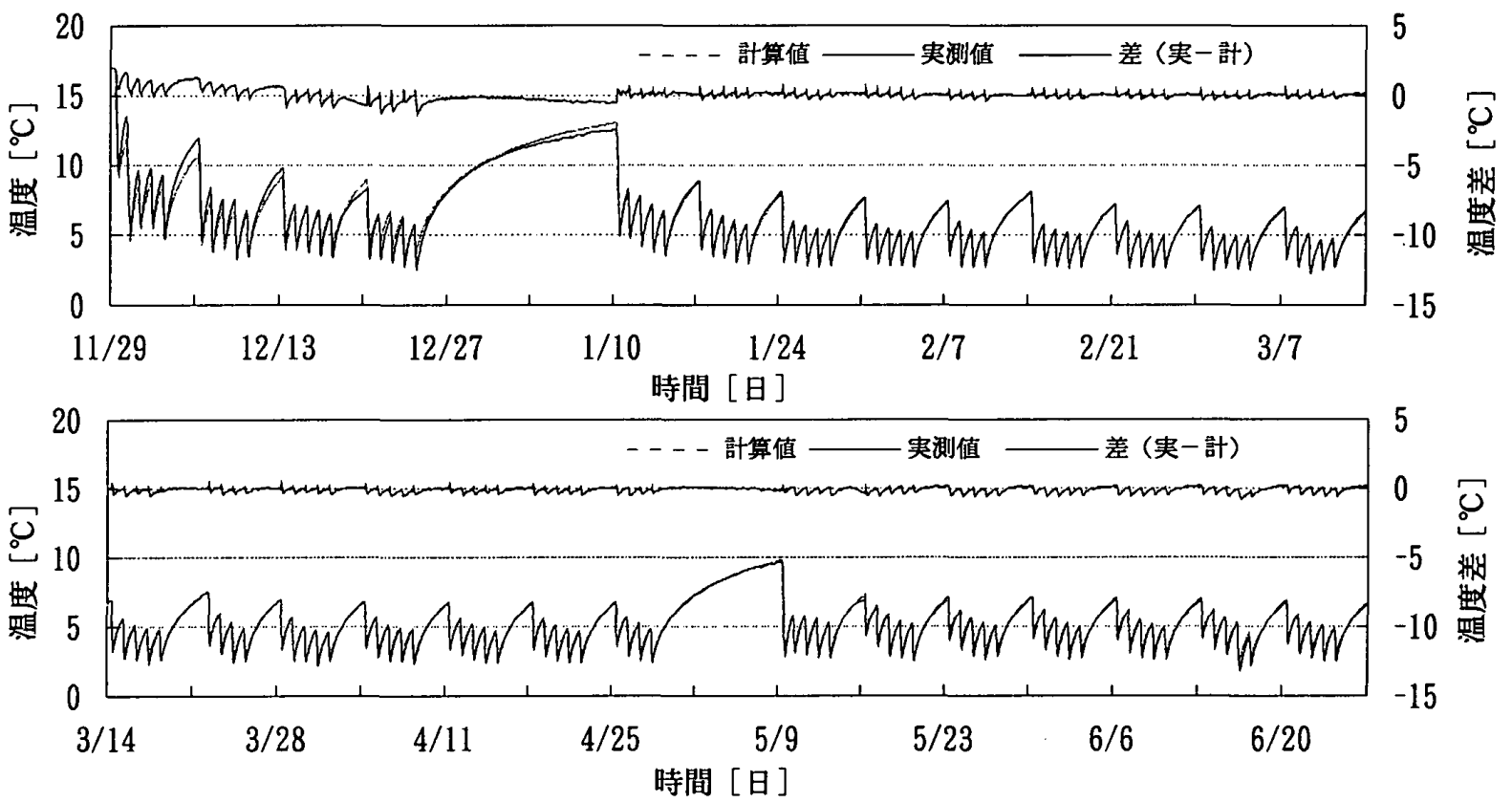

図 3 銅管内部水温の変動状況（実測值と計算値）

の蒸発器が循環水から採取した熱量で、冷水循環流量と 冷凍機の蒸発器出入口温度差から求めた。なお、実験で は陸上部における冷水循環系統の熱損失が存在するため、 $\mathrm{Q} Q \mathrm{R}=\mathrm{Q} \mathrm{Q} \mathrm{P}+\mathrm{Q} \mathrm{L}$ O S となる。QQCは、本システ 么の熱出力となる冷却水の放熱量で、冷却水の循環流量 と冷凍機の凝縮器出入口温度差から求めた。

本報では、採熱実験データのうち1993年11月29日から 1994年6月26日までの30週間の実験結果をまとめた。

なお、熱量計算は 5 分間隔の計测デー夕の 1 時間毎の 平均值を基にして行った。また、図 3 および図 4 に示す 実験結果と計算值の比較においては、実測值および計測 値とも 1 時間毎の值を示している。

\section{1 龬管杭内部水温の変動}

銅管杭内部の平均水温について、実測值と計算値の変 動状況を図 3 に示す。実測值より銅管杭内部水温は、採 熱運転開始から数日で急激に低下し、採熱運転停止後、 また土曜、日曜や長期の運転休止期間に自然回復してい るが、採熱連転の繰り返しにより徐々に低下する傾向を 見せている。しかし、1 週間每の運転サイクルにおける 初日の採熱運転開始直前の水温を見ると、3月以降は 7 ${ }^{\circ} \mathrm{C}$ 程度で、5 月の連休以降を含めてほぼ一定值となって おり、採熱運転に伴う銅管杭内部水温の変化のパターン は、3月以降ほほ定常的な状態となっているものと判断 される。

計算值と実測值の差は初期において $1 \sim 2{ }^{\circ} \mathrm{C}$ 程度とな っているが、1994年 1 月以降は採熱時および採熱停止後 とも、また、長期運転停止時の自然温度回復状況を含め て、実測値と良い一致を示している。実測値に対する計

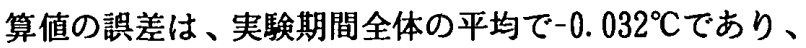

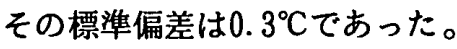

\section{2 鎙管杭からの採熱量}

鋼管杭からの採熱量と土壌からの熱伝導量の実測值と 計算值の変動状況を図 4 に示す。図において正の值は銅 管杭からの採熱量を示し、負の値は土壤からの熱伝導量 を示している。

図 4 より銅管杭からの採熱量の実測値について時間当 たりのピークの変化を見ると、採熱運転開始直後には 20 kIIと高い值を示しているが、採熱運転の継続にしたがっ て徐々に低下し、実験終盤では8k程度となっている。採 熱運転パターンを 5 日運転 2 日休止としているため運転 休止後の採熱量が大きく、週末に向かって徐々に低下し ていく傾向がある。長期運転休止後は水温が回復してい るため運転時間が長くなり 1 日当たりの採熱量が大きく なっている。採熱運転時間は、実験初期では 8 時間程度 であったが、第 3 週以降実験終了までは休日明けで 5 時 間程度、それ以外の日は $3 \sim 4$ 時間程度であった。

銅管杭からの採熱量の 1 週間の合計をその週の運転日 数で除した 1 日当りの平均熱量の変化を図 5 に示す。週 每の日平均採熱量は第 1 週には約 $70 \mathrm{kWh} /$ 日と高い値を示 しているが第 4 週にかけて急激に低下し、長期運転休止 後に一時回復したのち徐々に低下して行き、実験終盤で は約23kWh/日で安定した状況となっている。

採熱量の計算値は、時間当たりのピークが実測値と比 へてやや小さいものの実測値の変化の傾向と良く一致し ている。実測値に対する計算値の誤差は、運転時間の平

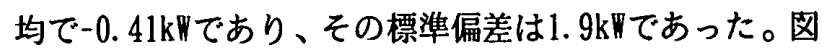
5 に示した週每の日平均採熱量も実験初期を除いて実測 值と良く一致している。銅管杭加の採熱量の実験期間 の総計は実測值で3945kWh、計算値で3716kWhであり、実 測値に対する計算值の差はー6\%であった。 

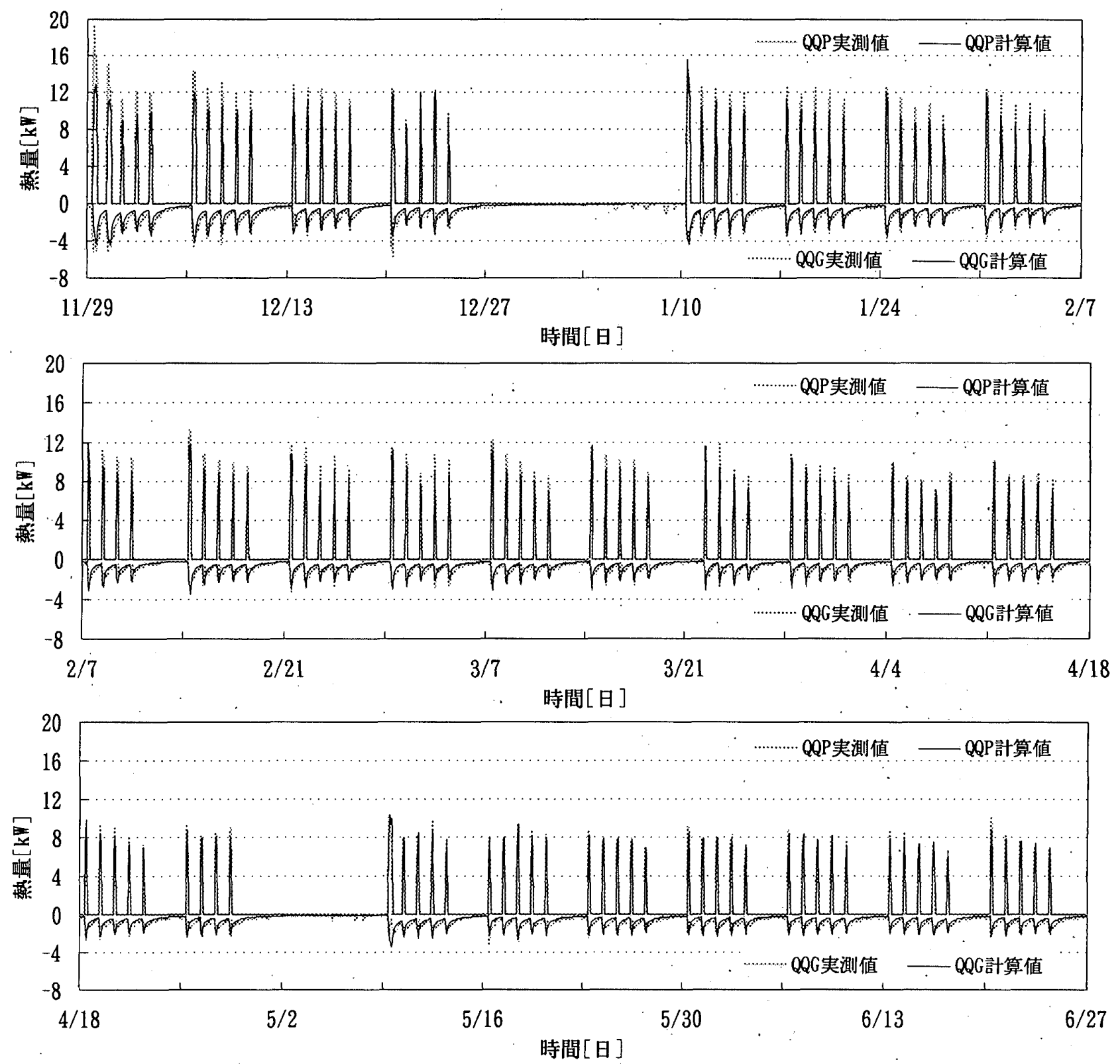

図 4 鋼管杭からの採熱量と土㙵からの熱伝導量の変動状況（実測值と計算値）

\section{3 土袞からの熱伝導量}

図 4において土埕からの熱伝導量の実測値の変化を見 ると、土㙋からの熱伝導量は、採熱運転開始之共に鋼管 杭内部水温が低下するため急激に增加するが、採熱運転 中にも次第に低下を始めていることが分かる。この原因 は土培の熱拡散率が小さいために、冷凍機の運転時間に おける土壌からの採熱領域が鋼管杭近傍に限られ、採熱 による土壤温度の低下速度か、冷凍機の運転による鋼管 杭内部水温の低下速度より大きくなり、両者の相対的な 温度差が徐々に小さくなって行くことによるものと考え られる。また、採熱運転終了後も周团土壌からの熱回収 は継続しているが、冷凍機運転停止後は鋼管杭内部水温 が土壤からの熱回収によって徐々に上昇するため、周囲 土袞との温度差はさらに小さくなって行く。このため、 土裹からの熱伝導量は時間の経過と共に徐々に低下して
おり、週末の運転休止 2 日目にはほほ０に漸近している。 実測值に関して時間当たりの熱伝導量のピークの変化 を見ると、採熱運転開始直後は $5 \mathrm{k}$ 程度を示しており、長 期運転休止後にも土壤温度が自然回復しているため大き な值となっているが、採熱運転の絽り返しにともない徐 タに低下して行き、第 30 週では $2 \mathrm{k}$ 程度となっている。

土壤からの熱伝導量の 1 週間の合計をその週の運転日 数で除した 1 日当りの平均熱量の変化を図 6 に示す。週 毎の日平均熱伝導量は第 1 週には約 $60 \mathrm{k} W \mathrm{~h} /$ 日を示してい るが第 4 週にかけて急激に低下し、長期運転休止後に回 復したのち採熱運転の継続と共に徐々に低下して行き、 実験終盤では約 $23 \mathrm{k} W \mathrm{~h} /$ 日で安定した状況となっている。

図 4 に示した土壌からの熱伝導量の実測値と計算値を 比べと、計算値はピークにおいて実測値よりやや小さ いものの実測値の変化と良く一致している。実測值に対 
する計算値の誤差は、全時間の平均で-0.14kであり、 その標準偏差は0.78kWであった。また、図 6 に示す週毎 の日平均熱伝導量の計算値も、実験初期を除いて実測値 と良く一致している。土壌からの熱伝導量の実験期間の 総計は実測值で3837kWh、計算值で3646k荝であり、実測 值に対する計算値の差はー $5 \%$ であった。

実測值を基にした 1 週間当たりの鋼管杭からの採熱量 に対する土境からの熱伝導量の割合を図 7 に示す。銅管 杭からの採熱量に対する土壤からの熱伝導量の割合は、 採熱運転開始直後や銅管杭内部水温が回復している長期 の運転休止直後を除いてほぼ100\%であり、本実験の採熱 運転条件では、䤲管杭からの採熱量のほとんどは土䇎か らの熱伝導量でまかなわれている。

4. 4 冷凍機採熱量と冷凍機供給熱量

冷凍機採熱量と冷凍機供給熱量について、それぞれの 熱量の 1 週間の合計をその週の運転日数で除した、1 日 当りの平均熱量の変化を図 8 に示す。

週毎の日平均冷凍機採熱量は採熱初期には $80 \mathrm{kWh} /$ 日程 度であり、実験中盤にかけて $30 \mathrm{kWh} /$ 日程度の最低値を示 し、実験終盤にかけては33kWh/日程度と若干增加してい る。冷凍機採熱量と図 5 に示した銅管杭からの採熱量の 差は循環水が鋼管杭を出た後の冷凍機回りの配管系から の熱損失によるものであり、冷凍機採熱量に対する配管 系からの熱損失の割合は 2 月、3 月の寒冷期には $10 \%$ 程 度であるが、4月以降の外気温が高い季節には $30 \%$ に達 している。実験終盤にかけて冷凍機採熱量が多少增加し たのは配管系統における熱損失の影響を受けたもので、 本実験では熱損失が採熱システムの運転にプラスの方向 に作用している結果となった。

冷凍機供給熱量の週毎の日平均熱量は、採熱初期には $100 \mathrm{kWh} /$ 日程度であり、冷凍機採熱量と同様に実験中盤に 約 $40 \mathrm{kWh} /$ 日の最低值を示し、実験終盤では $45 \mathrm{kWh} /$ 日程度 に増加した。実験終盤にかけて冷凍機供給熱量が增加し たのは、冷凍機採熱量が增加したためである。

4. 5 採熱運転におりる定常状態の判定

鋼管杭からの採熱量、土垪からの熱伝導量、冷凍機採 熱量ならびに冷凍機供給熱量について、それぞれの第30 週の日平均熱量を基準とした各週の日平均熱量の割合の 変化を図 9 に示す。

図 9 より各熱量の比率は第19週以降ほぼ1.0となってお り、採熱運転は定常状態になっていると判断される。

定常状態における各熱量の日平均熱量は表 2 に示すと おり、鋮管杭からの採熱量は23kW/日、土境からの熱伝 導量は $23 \mathrm{kWh} /$ 日、冷凍機採熱量は $30 \mathrm{kWh} /$ 日、冷凍機供給 熱量は $40 \mathrm{kWh} /$ 日となった。各熱量の第 1 週の日平均熱量 と比へた定常状態における值の割合は、銅管杭からの採 熱量がおよそ $30 \%$ となり、その他の熱量についてはいず れも $40 \%$ 程度となった。

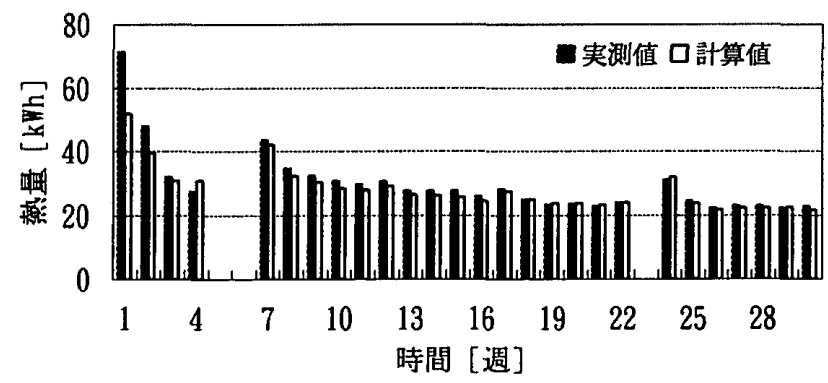

図 5 鋼管杭からの採熱量（週当たりの日平均値）

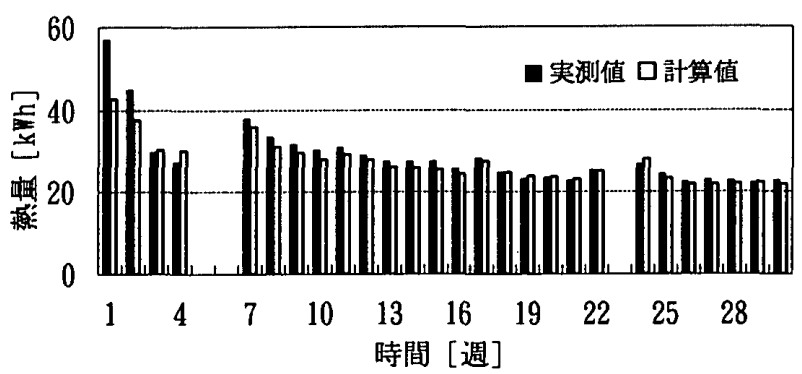

図 6 土溒からの熱伝導量（週当たりの日平均値）

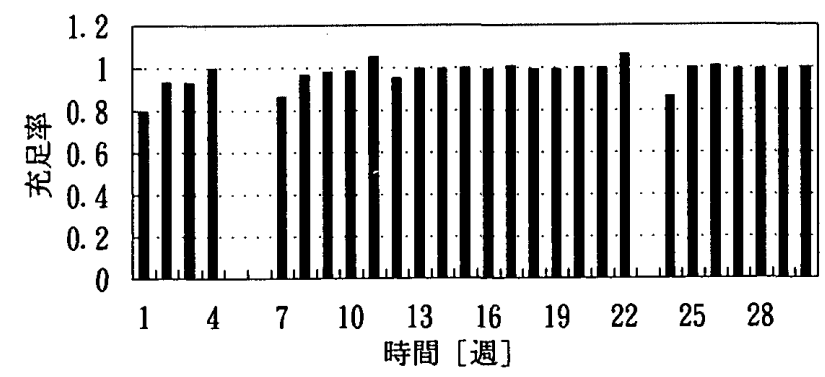

図 7 採熱量に対する土鏆からの熱伝導量の割合

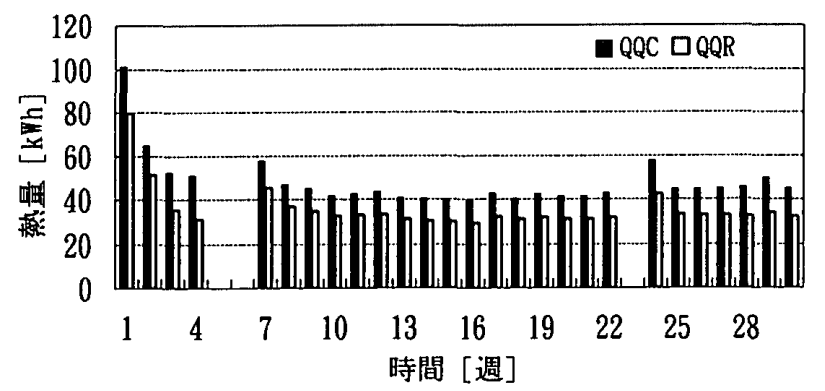

図 8 冷凍機供給熱量と冷凍機採熱量

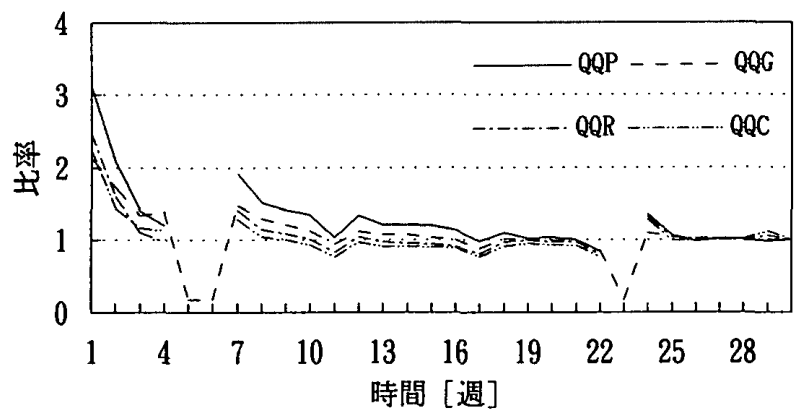

図 9 各種熱量の変化の割合 
なお、本論文で述へる定常状態とは、土境採熱システ ムの半年程度の運転期間において、鋼管杭と土壌との熱 交換量が安定的に一定と見なせる状態を指している。

4. 6 成績係数

冷凍機供給熱量 (QQC) と冷凍機採熱量 (QQR) に関する成績係数（ＣＯＰ）の変動状況を、冷凍機の蒸 発器と凝縮器の出入口平均水温を週平均値として求めた 値と共に図10に示す。ここでCＯPは、週間の冷凍機供 給熱量または冷凍機採熱量を週間の冷凍機消費電力量で 除したものである。

冷凍機供給熱量に対する C O P は、運転開始直後は 4 に近い值を示しているが定常状態では3.3程度となった。 冷凍機採熱量に対する C O P は運転開始值後は 3 程度を 示しているが定常状態では2.4程度となった。本実験にお ける冷凍機供給熱量に対するＣOPは、低水温熱源での 運転にもかかわらず比較的高い值を示した。

この時の蒸発器出入口水温の平均值は、第 9 週目以降 ほぼ安定して約 $4{ }^{\circ} \mathrm{C} て ゙$ 推移している。一方、凝縮器の出 入口平均水温は、放熱に冷却塔を使用しているため外気 温度の季節的変動の影響を受けて変化しており、第26週 以降の凝縮器温度の上昇が、採熱運転が定常状態に達し たと推定される第19週以降もＣＯＰの低下傾向が続いて いる原因となっている。

5. 計算モテルの長期性能評価への適用性

本計算法では、土壌採熱システムの性能評価において、 鋼管杭の埋設深度が深い場合には地表面からの外界気象 の影響は無視できると仮定しており、また、鋼管杭内部 水温を平均値で扱っている。

このような計算上の仮定が成立しなければ、短期の解 析において計算値と実測値が良い一致を示しても、長期 の解析では実測值との誤差が累積されて現れる可能性が ある。本計算方法が、鋼管杭による土墥採熱システムの 長期運転性能の評価に対して適用できることを確認する、 ためには、このような仮定が長期の計算においても成立 することを実験結果との検証で明らかにする必要があり、 また、本報告で得られた結果の一般性についても検討が 必要とされる。

\section{1 地表面の境界条件の扱い}

本実験において、鎆管杭から水平距離で約 $50 \mathrm{~m}$ 離れた 地点で計測した、土㙵温度の垂直分布の変動状況を図 11 に示す。図11より、外界気象の影響は浅いところに留ま っており、地下 $7 \mathrm{~m}$ 以深の土境温度は、ほぼ一定である ことが分かる。実験期間における各深さの計測点の平均 温度は、図11中に示すようになり、また、地下 $4 \mathrm{~m}$ の地 点では $17.2^{\circ} \mathrm{C}$ 平均値を基準に $\pm 1.2^{\circ} \mathrm{C}$ 等振幅で変動し ていることから、実験期間中の土壤温度は、 $4 \mathrm{~m}$ 以梁で
表 2 定常状態における各熱量の初期值に対する割合

\begin{tabular}{|l|c|c|c|}
\hline \multicolumn{1}{|c|}{ 熱量 [kWh/日] } & 初期值 & 定常値 & 定常/初期 \\
\hline 銅管杭からの採熱量 & 72 & 23 & 0.32 \\
\hline 土㙴からの伝熱量 & 57 & $: 23$ & 0.40 \\
\hline 冷凍機採熱量 & 80 & 30 & 0.38 \\
\hline 冾凍機供給熱量 & 101 & 40 & 0.40 \\
\hline
\end{tabular}

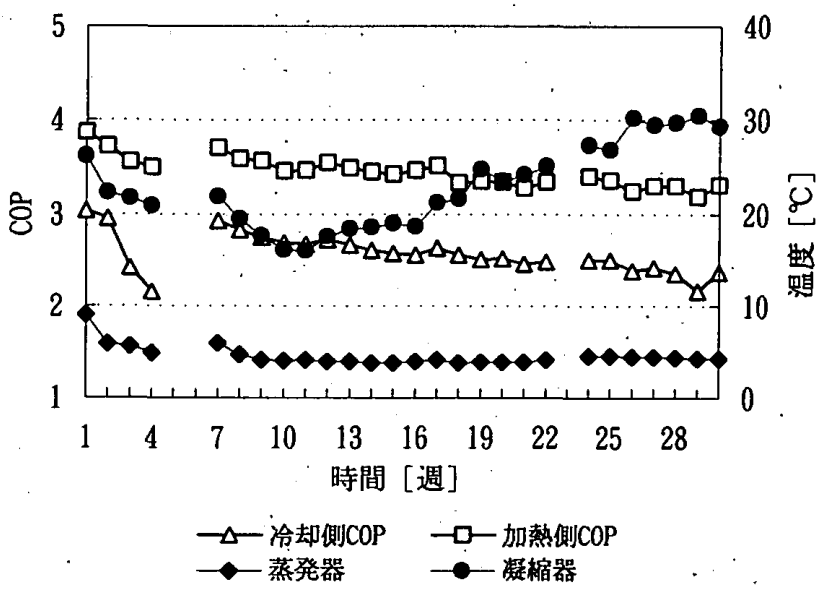

図10 冷凍機供給熱量に対する成績係数

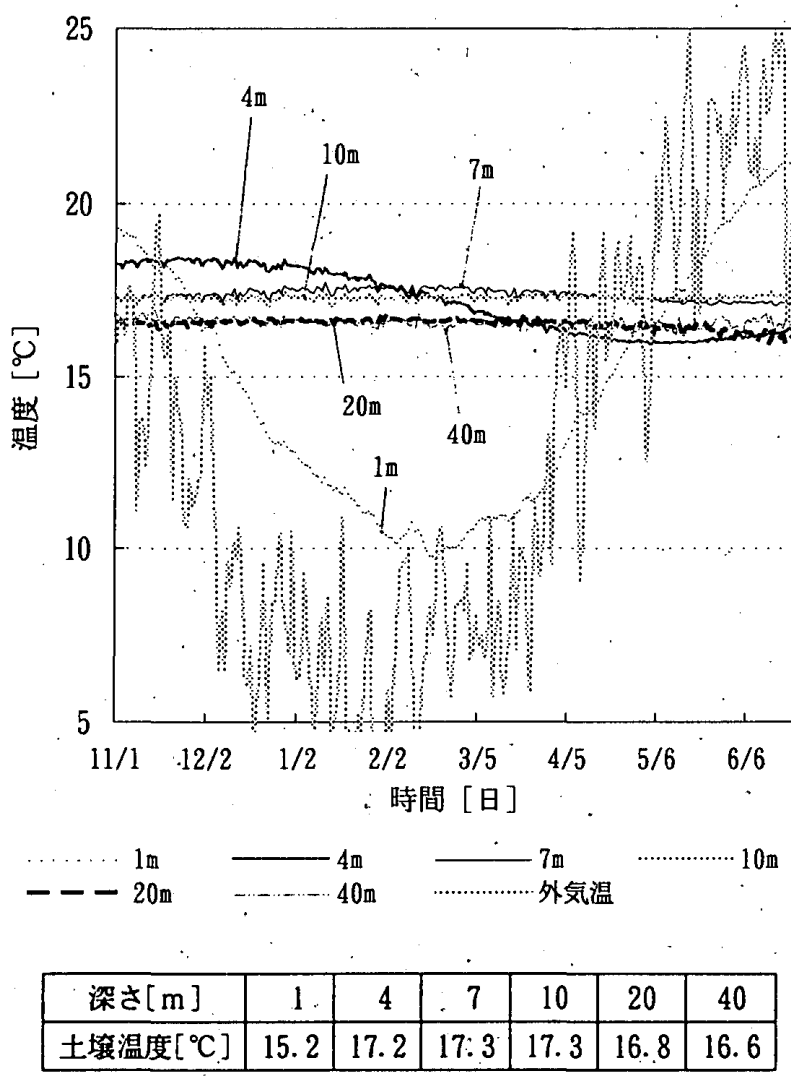

図11 土境温度の垂直分布 
$17^{\circ} \mathrm{C}$ 程度の均一温度として取り扱うことができると考え られる。

このような土壤温度の变動状況において、本報告では、 地表面における外界気象の変動か、土袞採熱システムの 熱的性能におよほ可影響は少ないと判断して、3．2に 述へたように地表面の境界条件を設定して計算を行った。

この結果、本報告で示した計算結果と実測值の比較に おいて、銅管杭内部水温の計算結果は、実測値に対して 長期にわたって良い一致を示し、また、銅管杭と土袞と の熱交換量の期間積算值の差は10\%以内となり、本計算 方法によって、鋼管杭による土境採熱システムの長期の 運転性能の予測が、実用上十分な精度を持って可能なこ とが確認された。

これは、本実験条件においては、土壌採熱システムの 運転性能に与える地表面からの外界気象の影響が少ない ことを示唆している。

この理由としては、龬管杭による土㙋熱利用システム では、鋼管杭が地下深くまで埋設されることから土境温 度の変動を受ける部分が少ないこと、また、地下数 $\mathrm{m}$ か ら不易層までの間の土垬温度は、深さに応した一定温度 を中心として、外界気象の年周期の変動に対して時間遅 れを伴いながら振動するため、計算において地表面の境 界温度として設定する不易層の温度から大幅にずれる期 間が短いこと、などが考えられる。

また、土墡温度は、地表面における外界気象の変動を

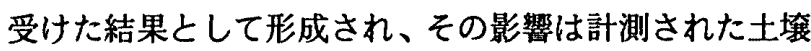
温度に既に反映されていると考えられることから、深さ 方向の土壌温度が均一、あるいは、その垂直分布がほと んど無いと見なせる場合には、鋼管杭による土墥採熱シ ステムの性能計算においては、一般的に、外界気象の影 㽧を考虑しなくても、十分な精度を持った性能評価が可 能であると言える。

しかし、外界気象の影響に関する厳密な検証は、実測 值を基準として、その変動を考虑した計算との比較で行 うへききであり、この点に関しては今後の課題として検討 して行きたい。

\section{2 銅管杭内部水温の平均値としての扱い}

本計算方法では(3)式に示したように、鋼管杭内部水温 を平均温度として扱っている。これは、蔇報で示した短 期実験では、銅管杭内部の水温がほとんど均一で変化し、 顕著な垂直水温の分布が観測されなかったことによる。 しかし、今回の実験では既報の実験と比へて、銅管杭の 直径と長さが大きくなり、龬管杭の容積に対する換水回 数が少なくなったため、鋼管杭内部の水温には図12に示 すような垂直分布が観測された。

図12は、採熱実験時の鋼管杭内部水温の垂直分布の典 型的な変動パターンとして、第14週目の計測結果を示し たもので、鋼管杭内部水温の計測点から奇数番号と(12)

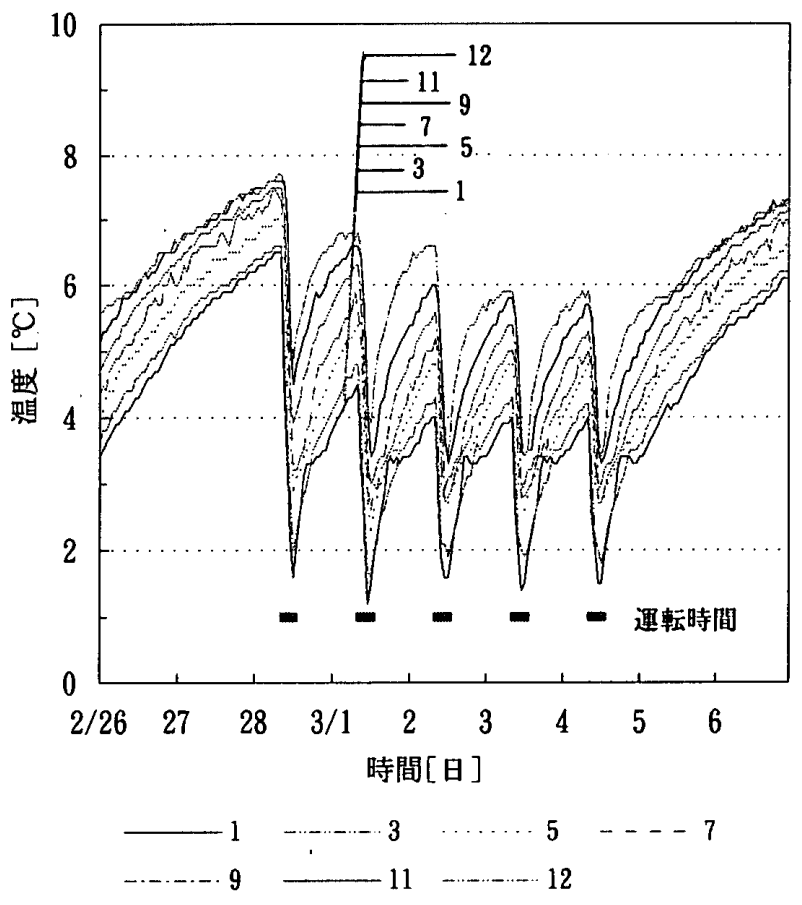

図12鋼管内部水温の垂直分布とその変動

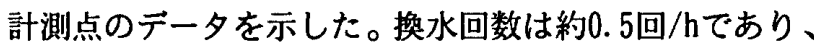
計測点(1)と(12)の温度差は、採熱運転時間において $3 \sim 3.5$ ${ }^{\circ} \mathrm{C}$ 程度、採熱運転停止後では $1.5 \sim 3^{\circ} \mathrm{C}$ 程度であり、銅管 杭の長さ方向に直線的な温度勾配を持った温度成層を形 成して推移している。

本報告で示した計算では、鋼管杭上下の温度差が最大 で3. $5^{\circ} \mathrm{C}$ 程度あるものの、䤡管杭内部水温が直線的な温度 勾配を示しながら変動しており、温度成層の状況から見 て、銅管杭と土袞との熱交換が深さ方向で均等に行われ ていると考えられることから、銅管杭内部水温を平均値 として扱っても、交換熱量の積分に関する誤差は小さい と判断して計算を行った。

この結果、本報告で示した計算結果と実測値の比較に おいて、鋼管杭内部水温の計算值は、温度成層を形成し た実測値の平均値に対して長期にわたって良い一致を見 せ、また、銅管杭と土滾との熱交換量に関する計算値と 実測值との差も十分小さいことから、鋼管杭による土袞 採熱システムの長期性能評価において、本計算方法が、 十分な精度を持って適用できることが確認された。

これより、実際の現象として龬管杭内部の水に温度成 層が生じても、その深さ方向の温度差が小さく、温度勾 配が直線的であるような場合には、鋼管杭による土壤採 熱システムの性能予測に対して本計算方法がとっている、 鋼管杭内部水温の平均值としての扱いは、妥当ものと判 断される。

なお、本計算法が適用できる上下温度差の範囲や、よ り大きな直径の鋼管杭や地下蓄熱槽などに対する適用性 については、今後の検討課題である。 


\section{6.まとめ}

本報告は、地中に埋設した直径 $0.6 \mathrm{~m}$ 、長さ $22.5 \mathrm{~m}$ の鍓 管杭によって土裹からの摇熱実験を行い、龬管杭と土堷 との長期にわたる熱交換特性を明らかにすると共に、既 報14)で示した計算モテルの長期にわたる採熱性能の予測 に対する適用性を検討したものである。

本研究において得られた結論を要的して以下に示す。 なお、ここで示す結論は、本実験条件の範囲で適用され るものである。

\section{1）実験結果から、}

(1)定常状態における鋼管杭からの採熱量は23kWh/日で、 初期採熱量のおよそ 3 分の 1 となった。

(2)定常状態における土踑からの熱伝導量は $23 \mathrm{kWh} /$ 日で初 期熱伝導量の約 $40 \%$ となった。

(3)定常状態における銅管杭からの採熱量は、土壤からの

熱伝導量によってほほ100\%まかなわれている。

(4)冷凍機供給熱量に対するCOPは、定常状態において 3.3 と高い値を示した。

2 ）実験結果之計算結果の比較から、

(1)鋼管杭内部水温、鋼管杭からの採熱量および土墱から の熱伝導量に関して、計算値は実測值に良好に一致し、 本計算モデルが長期の採熱性能の予測に適用できるこ とが確認された。

(2)実現象として鋼管杭内部の水に温度成首が生じても、 その深さ方向の温度差が小さく、温度勾配が直線的で あれば、銅管杭と土袞との伝熱計算においては、銅管 杭内部水温を平均温度として取り扱うことが出来る。

本研究の結果から、鋼管杭を用いた土㙵採熱システム の定常状態における熱交換特性を明らかにすることがで き、実験結果との検証により既報 ${ }^{14)}$ で開発した計算モデ ルによって、鋼管杭を土㙵との熱交換器とした場合の長 期の採熱性能の予測が可能であることが確認された。

これによって、鋼管杭を土䖯との熱交換器とした土壤 採熱システムの長期にわたる信頼性を持った設計が可能 になったと判断される。

しかし、本計算方法の適用範囲については、5 章で述 へたような、さらなる検討の予知が残されており、今後 の課題としたい。

今後の土境採熱システムの実用化に際しては、数年間 にわたる周期的な採熱運転に伴う土裹温度の変動状況を 評価することが必要であり、今後は、この点についても 検討を進めると共に、鋼管杭を利用した土㙵熱利用シス テムのパラメーター解析を進め、土壤熱利用システムの 実用化に向けて努力して行きたい。
謝辞

本研究の実施に当たりこ指導をいただいた清水建設(㑣) 技術研究所設備技術研究部小林部長之、実験の実施と $\vec{~}$ 一夕のまとめにこ協力いただいた、清水建設(侏技術研究 所設備技術研究部内田泰雄君に、記して感謝の意を表し ます。

参考文献

1) Ball D.A., Fisher R. D. :Design methods for Ground-Source Heat Pumps, US DOE Rep. CONF-830640-5 , 1983

2) Bose J.E. et al. :Design/Data Hanual for Closed-loop Ground-coupled Heat Pump Systems, ASHRAE, 1985

3) Hogensen P. :The European Market, 土弶熱源ヒートポンプ国際 論文集、pp. 19-28、(財)ヒートポンプ技術開発センター、1991

4) Sanner B. , Knoblich K. :Subsurface Cold Storage in Ground Coupled Heat Pump Systems. Proceedings -5 th Inter. Conf. on Thermal Energy Storage, pp. 2.4-1, 1991

5）長野克則、落藤澄、中村真人、中村卓司、西片一成、若山尚之 : 水平埋設管による土境の採熱実験と採熱特性のシミュレーション、 空気調和・衙生工学会学術講演会䇎演論文集、pp. 33-36、 1992. 10

6）落藤澄、西岡䢁二、長野克則、中村真人：垂直埋設管を用いた不 凍液语懪型ヒートポンプによる土墱採熱の実験と解析、空気勍和 - 衛生工学会論文集、No. 51、pp. 103-111、1993.2

7）落藤澄、長野克則、山田健一、中村卓司：土境採熱における直澵 式ヒートポンプのシミュレーション、空気調和・衛生工学会学術 講演会䇎演論文集、pp. 737-740、1990.10

8) Nishioka J. :Operating Experience with Ground-Source Heat Pump System, Proceedings - The 3rd International Energy Agency Heat Pump Conf.. pp. 297-306. 1990

9）松本街、永井久也、牛尾智秋：ヒートポンプ熟源としての地盤熱 利用に関す万研究、杂気調和・衙生工学会学術講演会講演論文集、 pp. 217-220、1993.10

10）大橋一正、中村准二、片山和夫、佐川裙一郎、石黑邦道、末松 英樹 : 建物を利用した地中熱利用ヒートポンプシステムの鶁算、 空気調和・衡生工学会学術講演会講演諭文集、pp. 273-276、 1991

11）竹内正紀、木村照夫、宮本重信、评田諭治：基碳くい利用地熱 融雪法の開発と数使シミュレーション、空気調和・衛生工学会 論文集、No. $52 、$ pp. 59-69、1993.6

12）岡建雄、滕田尊志: 土壤熱利用ヒートポンプシステム、建策設 備之配管工事、pp. 73-77、1989. 10

13）宮本重信 : 摆境にやさしい融雪をめざして、土木学会誌、 VOL. 78 , No. 5, pp. $6-9,1993.5$

14）森野仁夫、岡建婎：銅管杭による土境故熱・採熱に関す万研究、 日本建第学会㖕画系論文報告集、No. $404 、$ pp. 49-57、1989.10

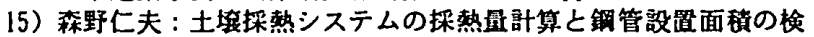
討、日本建策学会大会学術講演梗概集、pp. 1087-1088、1992.8

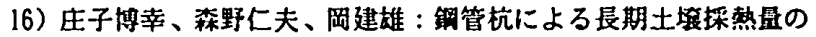
予测に関する检討、日本建築学会大会学術請演概集、 pp. 443-444、1994.9

17) Farouki 0.T. :Thermal Properties of Soils, Trans Tech. Publications, pp. 103-107. 1986

18）河原斺久、後迫成、後滕政：地下水流水中に設滥されたヒート

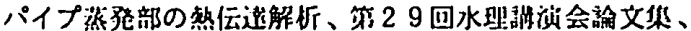
pp. 887-892、1985.2

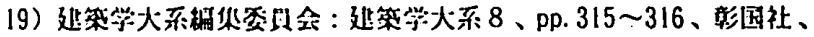
1969 